\title{
OCCURRENCE OF MACROBRACHIUM AMAZONICUM (HELLER) (DECAPODA, PALAEMONIDAE) IN LEOPOLDO'S INLET (RESSACO DO LEOPOLDO), UPPER PARANÁ RIVER, PORTO RICO, PARANÁ, BRAZIL
}

\author{
Andréa Bialetzki ${ }^{1}$ \\ Keshiyu Nakatani ${ }^{1}$ \\ Gilmar Baumgartner ${ }^{1}$ \\ Georgina Bond-Buckup ${ }^{2}$
}

\begin{abstract}
Studies on the occurrence, temporal distribution and nychthemeral variation of Macrobrachium amazonicum (Heller, 1862) were undertaken in Leopoldo's Inlet, upper Paraná River, Porto Rico, Paraná, Brazil. Seventeen thousand and sixty specimens (11,786 larvae and 5,274 juveniles) were captured with a conicalcylindrical plankton net of mesh $0.5 \mathrm{~mm}$ in monthly samples between February 1991 and February 1992. Results show that the greatest densities of larvae (301.83 larvae $\left./ 10 \mathrm{~m}^{3}\right)$ and juveniles $\left(168.8 / 10 \mathrm{~m}^{3}\right)$ of this species were caught in December 1991. Largest captures were made during the night. With regard to abiotic factors water temperature ranged from $20^{\circ}$ to $30^{\circ} \mathrm{C}, \mathrm{pH}$ ranged from 5.66 to 7.37 and electric conductivity ranged from 51.83 to $65.33 \mu \mathrm{S} / \mathrm{cm}$. Relationship between the density of larvae and juveniles and abiotic factors was calculated by the Principal Components Analysis (PCA) which revealed the influence of some limnological variables especially on the distribution of larvae.

KEY WORDS. Decapoda, Palaemonidae, Macrobrachium amazonicum, temporal distribution, nychthemeral variation, Paraná River
\end{abstract}

Since some species of freshwater shrimps have a high economical quotation, studies have been undertaken, chiefly on the genus Macrobrachium (Bate, 1868), in different regions of Brazil with regard to the general ecological and biological aspects of these organisms. Among these studies mention should be made of the research works of GOMES-CORRÊA (1977), LOBÃO \& SAWAYA (1979), CARVALHO et al. (1979), ELMOR et al. (1981), BOND-BUCKUP \& BUCKUP (1982, 1983), COElHo et al. (1982), CoElHo \& RAMOS-PORTO (1985), LoBÃo et al. (1986a), ODINETZ-COLLART (1988), BOND-BUCKUP \& BUCKUP (1989), among others.

The species that has been studied with much frequency is Macrobrachium amazonicum (Heller, 1862), popularly known as "camarão-canela" or "camarãosossego". According to HolTHUIS (1952) and GOMES-CORREA (1977) the species

1) Departamento de Biologia, Nupélia, Universidade Estadual de Maringá. Avenida Colombo $5790,87020-900$ Maringá, Paraná, Brasil.

2) Departamento de Zoologia, Universidade Federal do Rio Grande do Sul. Avenida Paulo Gama 40, 90040-060 Porto Alegre, Rio Grande do Sul, Brasil. 
is widely distributed and is found in the basins of north of South America, of the Amazon River, of northeastern Brazil, of the São Francisco River and of the Paraguay River. In the Amazon River, its place of origin, it is found in high densities and constitutes about $80 \%$ of the macrocrustacean biomass of the floodplains (ODINETZ-COLLART 1993).

With an aim at repopulation programs the São Paulo Energy Company (CESP) introduced various fish species from dams found in the North and Northeastern regions of Brazil. Macrobrachium amazonicum was introduced to feed these fish (TORLONI et al. 1993). Apparently they adapted themselves well to the new habitat and spread throughout the floodplain of the upper Paraná River. At present they are an important link in the alimentary chain of this environment. The aim of the present paper is to analyse the occurrence, temporal distribution and nychthemeral variation of $M$. amazonicum and its relationship with some abiotic variables. It will thus contribute to the ecology and biology of this species in the region.

\section{MATERIALS AND METHODS}

\section{Characteristics of the area}

Leopoldo's Inlet $\left(22^{\circ} 45^{\prime} \mathrm{S}\right.$ and $\left.53^{\circ} 16^{\prime} \mathrm{W}\right)$ lies on the right margin of Porto Rico island, upper Paraná River, municipality of Porto Rico, Paraná, Brazil (Fig. $1)$.

The environment is lentic almost all the year round, linked constantly to the Paraná River and has a greater flow when the rising of the fluviometric level occurs. It may extend up to $1,100 \mathrm{~m}$.

Margins are flooded owing to their slight declivity. The greatest depth during flooding may reach up to four meters, diminishing at the extremely shallow margins. Sediment is muddy, rich in organic material and the riparian vegetation is characterized by the presence of species typical of floodplains such as Poaceae, Polygonum spp, shrub formations and some trees. The embaúba, Cecropia pachystachya (Trec., 1924), is the most frequent species (CAMPOS \& SoUZA 1997).

\section{Methods}

Captures were made monthly from February 1991 to February 1992 throughout the nychthemeral cycles with four hour intervals between them. Conicalcylindrical plankton net were used with mesh $0.5 \mathrm{~mm}, 1.5 \mathrm{~m}$ in length and $0.375 \mathrm{~m}$ diameter at the mouth. The net was dragged at the water level during 10 minutes with the boat at low speed. Filtered water was obtained from a fluxometer joined to the mouth of the net. Samples of captured plankton were fixed in $4 \%$ formaldehyde solution. Temperature $\left({ }^{\circ} \mathrm{C}\right)$, electric conductivity $(\mu \mathrm{S} / \mathrm{cm})$ and $\mathrm{pH}$ of the water at the surface were recorded. However, these last two parameters were obtained only as from September 1991 due to lack of equipment. Estimates of pluviometric index and fluviometric level were obtained from the climatological station of the National Department of Water and Electrical Energy (DNAEE) at Porto São José, Paraná, Brazil. 


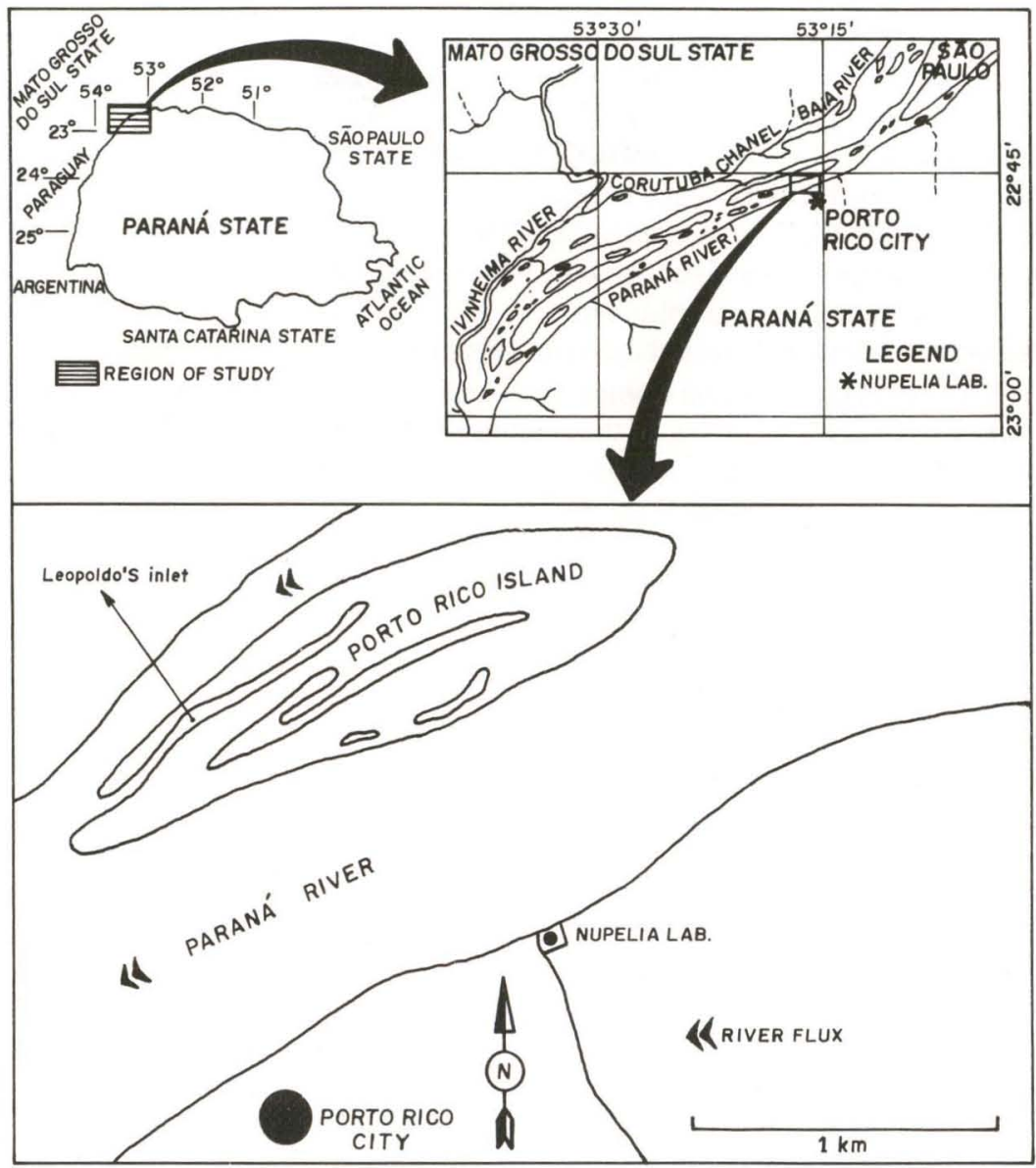

Fig. 1. Site of the sampling station.

Samples of $M$. amazonicum were separated from the other plankton in the laboratory by using a stereoscopic microscope and Bogorov's acrilic plate. Sample standardization was undertaken for a volume of $10 \mathrm{~m}^{3}$ of filtered water. Identification of individuals was based on their external morphology according to HoLTHUIS's (1952) criteria. Distinction between larvae and juveniles was done according to MAGALHÃES (1985).

Relative density was calculated according to the following formula:

$$
D R=\frac{N}{C}
$$

where: (DR) relative density of larvae/juveniles (ind $/ 10 \mathrm{~m}^{3}$ ); (N) total number of larvae/juveniles collected; $(\mathbf{C})$ number of months in which larvae/juveniles occurred. 
For a better view of results the graphs for temporal distribution and nychthemeral variations are given in logarithmic scales. Association between the abiotic variables and larvae and juvenile densities was undertaken through the Principal Components Analysis (PCA) and its aim was to verify interdependence among the variables (MANLY 1995). Data referring to the period of the greatest capture of individuals, or rather, from September 1991 to February 1992 were used. Data matrix was composed by five variables (water temperature, $\mathrm{pH}$, electric conductivity, fluviometric level and pluviometric index) and 36 observations. Data were previously standardized since they were units of distinct measurements.

Scores of the Principal Compenents Analysis applied to the abiotic data were used as explanatory variables of the organisms' densities which were previously given in logarithms with the addition of a constant (1).

\section{RESULTS}

\section{Abiotic variables}

Average abiotic variables obtained during the period are on table I

Table I. Average of abiotic data obtained at Leopoldo's Inlet. (WT) Water temperature, (EC) electric conductivity, (FL) fluviometric level, (PI) pluviometric index.

\begin{tabular}{lccccr}
\hline \multicolumn{1}{c}{ Month } & $\begin{array}{c}\mathrm{WT}^{*} \\
\left({ }^{\circ} \mathrm{C}\right)\end{array}$ & $\mathrm{pH}^{*}$ & $\begin{array}{c}\mathrm{EC}{ }^{*} \\
(\mu \mathrm{S} / \mathrm{cm})\end{array}$ & $\begin{array}{l}\mathrm{FL}^{*} \\
(\mathrm{~cm})\end{array}$ & $\begin{array}{r}\mathrm{PI}^{* *} \\
(\mathrm{~mm})\end{array}$ \\
\hline February/1991 & 25.41 & & & 449 & 57.0 \\
March & 20.58 & & 540 & 40.0 \\
April & 23.33 & & 549 & 53.6 \\
May & 20.58 & & 284 & 35.4 \\
June & 20.00 & & & 354 & 74.4 \\
July & 20.50 & & & 296 & 2.2 \\
August & 25.50 & & & 273 & 9.4 \\
September & 27.33 & 5.84 & 58.58 & 266 & 57.8 \\
October & 26.50 & 5.66 & 51.83 & 261 & 47.4 \\
November & 27.33 & 7.27 & 51.88 & 324 & 71.6 \\
December & 27.42 & 6.63 & 61.47 & 299 & 181.6 \\
January/1992 & 29.17 & 7.37 & 54.83 & 385 & 88.2 \\
February & 30.00 & 6.02 & 65.33 & 393 & 82.2 \\
\hline
\end{tabular}

*. Average data with regard to days of capture; ${ }^{* \star}$. monthly average data.

Water temperature values ranged from $20^{\circ}$ to $30^{\circ} \mathrm{C}$ with lower values in June 1991 and highest in February 1992, presenting a clear seasonal factor throughout the year. With regard to $\mathrm{pH}$ and electric conductivity lack of data from February to August 1991 does not permit annual possible variation. However, $\mathrm{pH}$ ranged from 5.66 in October 1991 to 7.37 in January of the same year. Electric conductivity ranged from 51.83 to $65.3 \mu \mathrm{S} / \mathrm{cm}$. The lowest value was obtained in October 1991 and the highest in February 1992. 
Values of fluviometric level, pluviometric index and water temperature varied according to the season. River level presented lower values in October with $261 \mathrm{~cm}$ and the highest values were obtained in April 1991 with $549 \mathrm{~cm}$. The pluviometric index presented great variations oscillating between $2.2 \mathrm{~mm}$ (July 1991) and 181.6mm (December 1991).

\section{Temporal Distribution and Nychthemeral Variation}

Data on monthly captures of larvae and juveniles are shown in figure 2. The temporal distribution of these organisms shows that captures occur in almost throughout the whole period with highest occurrences in the spring/summer months. The average greatest densities of larvae captures occurred in December 1991 with 301.83 larvae $/ 10 \mathrm{~m}^{3}$. This was followed by captures in September with 18.95 larvae $/ 10 \mathrm{~m}^{3}$ and in October 1991 with 13.86 larvae $/ 10 \mathrm{~m}^{3}$. With regard to juveniles the months with the greatest densities were December 1991 with 168.8 juveniles $/ 10 \mathrm{~m}_{3}^{3}$, November with 72.19 juveniles $/ 10^{3}$ and October with 10.16 juveniles $/ 10 \mathrm{~m}^{3}$.

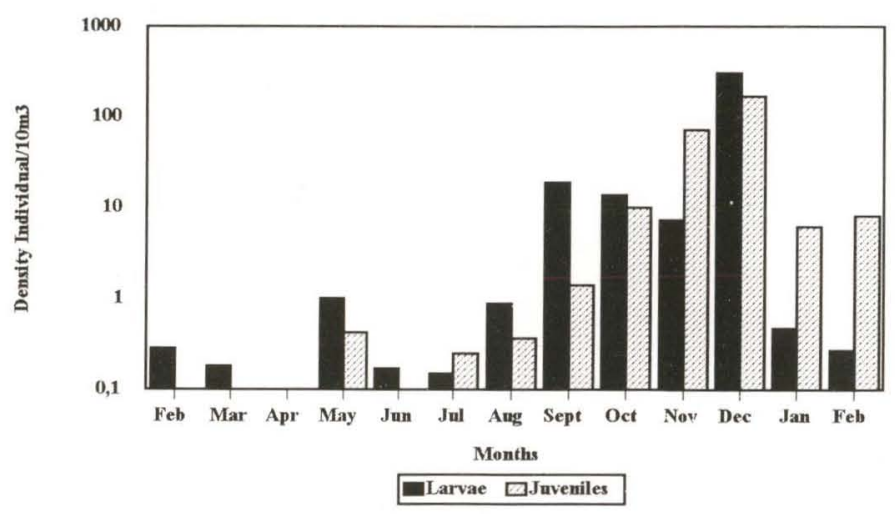

Fig. 2. Monthly relative densities of Macrobrachium amazonicum larvae and juveniles captured in Leopoldo's Inlet.

The nychthemeral variation of individuals is shown in figure 3. Captures at different times show that for both stages the greatest captures occurred during the night. The peak of larvae capture was observed to be at 21:30 hours $(125.83$ larvae $\left./ 10^{3}\right)$; the smallest density occurred at $9: 30$ hours with 16.81 larvae $/ 10 \mathrm{~m}^{3}$. With regard to variation of juveniles, they seem to have a similar behaviour to that of the larvae: the greatest density was observed at $1: 30$ hours $\left(69.89\right.$ juveniles $\left./ 10 \mathrm{~m}^{3}\right)$ and the smallest at 9:30 hours $\left(0.95\right.$ juveniles $\left./ 10 \mathrm{~m}^{3}\right)$.

\section{Relationship between abiotic variables and density of organisms}

Analyses of relationship between the principal components and the densities of organisms were undertaken by means of data referring to the period of greatest capture as shown in table II. 


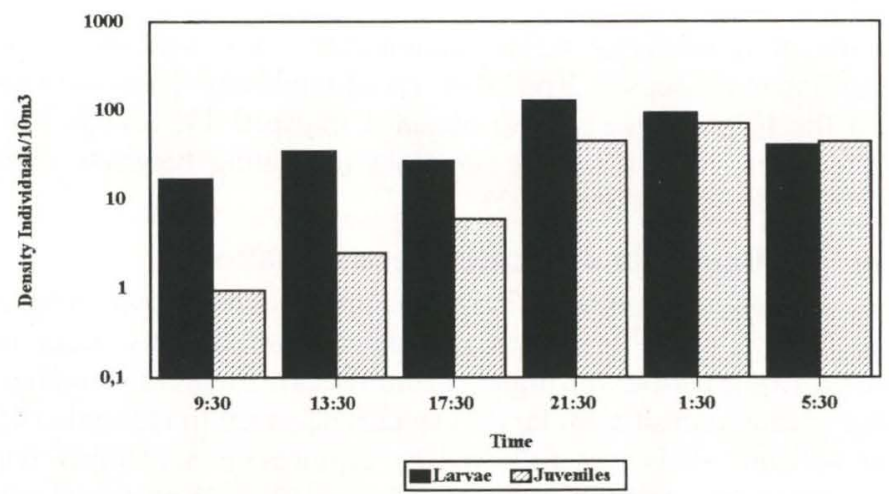

Fig. 3. Relative densities of larvae and juveniles of Macrobrachium amazonicum captured during nychthmeral cycles in Leopoldo's Inlet.

Table II. Abiotic data and densities of larvae and juveniles in captures at Leopoldo's Inlet from September 1991 to February 1992. (Wt) Water temperature, (EC) electric conductivity, (FL) fluviometric level, (PI) pluviometric index, (DL) density of larvae, (DJ) density of juveniles).

\begin{tabular}{|c|c|c|c|c|c|c|c|c|}
\hline Month & Time & $\begin{array}{l}\text { WT * } \\
\left({ }^{\circ} \mathrm{C}\right)\end{array}$ & $\mathrm{pH}^{*}$ & $\begin{array}{c}E C^{*} \\
(\mu \mathrm{S} / \mathrm{cm})\end{array}$ & $\begin{array}{l}\mathrm{FL}^{*} \\
(\mathrm{~cm})\end{array}$ & $\begin{array}{l}\mathrm{PI} \text { ** } \\
(\mathrm{mm})\end{array}$ & $\begin{array}{c}D L^{*} \\
\left(10 m^{3}\right)\end{array}$ & $\begin{array}{c}\mathrm{DJ} \text { * } \\
\left(10 \mathrm{~m}^{3}\right)\end{array}$ \\
\hline \multirow[t]{6}{*}{ September/1991 } & $09: 30$ & 25.0 & 5.83 & 57.5 & 266 & \multirow[t]{6}{*}{57.8} & 40.67 & 0.00 \\
\hline & $13: 30$ & 26.0 & 5.93 & 56.5 & 265 & & 3.50 & 0.00 \\
\hline & $17: 30$ & 28.0 & 5.99 & 56.0 & 265 & & 11.44 & 0.00 \\
\hline & $21: 30$ & 30.5 & 5.82 & 58.0 & 265 & & 17.85 & 1.42 \\
\hline & $01: 30$ & 27.5 & 5.72 & 64.0 & 266 & & 14.83 & 0.00 \\
\hline & $05: 30$ & 27.0 & 5.77 & 59.5 & 266 & & 25.86 & 0.00 \\
\hline \multirow[t]{6}{*}{ October } & $09: 30$ & 26.5 & 5.83 & 54.0 & 264 & \multirow[t]{6}{*}{47.4} & 0.22 & 0.67 \\
\hline & $13: 30$ & 26.0 & 5.95 & 52.0 & 257 & & 0.23 & 0.00 \\
\hline & $17: 30$ & 27.0 & 5.72 & 51.0 & 257 & & 41.26 & 0.00 \\
\hline & $21: 30$ & 26.5 & 5.45 & 50.0 & 257 & & 27.77 & 18.20 \\
\hline & $01: 30$ & 27.0 & 5.46 & 52.0 & 264 & & 8.20 & 15.51 \\
\hline & $05: 30$ & 26.0 & 5.57 & 52.0 & 264 & & 5.49 & 6.24 \\
\hline \multirow[t]{6}{*}{ November } & $09: 30$ & 29.0 & 7.45 & 50.6 & 324 & \multirow[t]{6}{*}{71.6} & 2.40 & 2.40 \\
\hline & $13: 30$ & 28.0 & 7.24 & 49.7 & 324 & & 1.58 & 6.71 \\
\hline & $17: 30$ & 28.0 & 7.81 & 58.1 & 324 & & 0.81 & 5.85 \\
\hline & $21: 30$ & 26.0 & 7.13 & 50.8 & 324 & & 33.65 & 256.18 \\
\hline & $01: 30$ & 26.0 & 6.92 & 50.8 & 323 & & 4.25 & 159.99 \\
\hline & $05: 30$ & 27.0 & 7.06 & 51.3 & 323 & & 1.35 & 2.03 \\
\hline \multirow[t]{6}{*}{ December } & $09: 30$ & 27.0 & 6.80 & 54.7 & 293 & \multirow[t]{6}{*}{181.6} & 73.52 & 0.00 \\
\hline & $13: 30$ & 27.3 & 6.60 & 64.0 & 293 & & 271.32 & 0.00 \\
\hline & $17: 30$ & 27.3 & 6.60 & 63.3 & 293 & & 104.26 & 0.00 \\
\hline & $21: 30$ & 27.7 & 6.70 & 63.6 & 293 & & 549.42 & 52.71 \\
\hline & 01:30 & 27.7 & 6.60 & 63.3 & 304 & & 526.63 & 225.94 \\
\hline & $05: 30$ & 27.5 & 6.50 & 59.9 & 304 & & 285.85 & 227.55 \\
\hline
\end{tabular}

(Continues) 
Table II. Continuation.

\begin{tabular}{cccccccrr}
\hline Month & Time & $\begin{array}{c}\mathrm{WT}^{*} \\
\left({ }^{\circ} \mathrm{C}\right)\end{array}$ & $\mathrm{pH}^{*}$ & $\begin{array}{c}\mathrm{EC}{ }^{*} \\
(\mu \mathrm{S} / \mathrm{cm})\end{array}$ & $\begin{array}{r}\mathrm{FL}^{*} \\
(\mathrm{~cm})\end{array}$ & $\begin{array}{c}\mathrm{PI}^{* *} \\
(\mathrm{~mm})\end{array}$ & $\begin{array}{r}\mathrm{DL}^{*} \\
\left(10 \mathrm{~m}^{3}\right)\end{array}$ & $\begin{array}{r}\mathrm{DJ}^{*} \\
\left(10 \mathrm{~m}^{3}\right)\end{array}$ \\
\hline January/1992 & $09: 30$ & 32.0 & 6.90 & 57.1 & 364 & 88.2 & 0.00 & 0.21 \\
& $13: 30$ & 34.0 & 7.50 & 55.3 & 364 & & 0.00 & 0.16 \\
& $17: 30$ & 34.0 & 7.70 & 52.4 & 364 & & 0.00 & 0.00 \\
& $21: 30$ & 26.0 & 7.80 & 53.5 & 364 & & 0.47 & 19.69 \\
& $01: 30$ & 26.0 & 7.40 & 55.0 & 405 & & 0.00 & 10.29 \\
& $05: 30$ & 23.0 & 6.90 & 55.7 & 405 & & 0.00 & 0.33 \\
& $09: 30$ & 30.0 & 5.83 & 61.0 & 371 & 82.2 & 0.00 & 0.95 \\
& $13: 30$ & 31.0 & 5.91 & 61.0 & 371 & & 0.24 & 2.45 \\
& $17: 30$ & 30.0 & 6.26 & 61.0 & 414 & & 0.30 & 5.85 \\
& $21: 30$ & 29.5 & 6.19 & 66.0 & 414 & & 0.00 & 44.80 \\
& $01: 30$ & 29.5 & 5.97 & 76.0 & 371 & & 0.00 & 69.89 \\
& $05: 30$ & 30.0 & 5.97 & 67.0 & 371 & & 0.00 & 43.27 \\
\hline
\end{tabular}

*. Data obtained in days of the capture; ${ }^{* *}$. average monthly data.

Among the five possible principal components only the first three were used for interpretation since they were the only ones with autovalues higher than 1.0 (Kaiser-Guttman's criterion). Principal components I, II and III together explained $84 \%$ of the abiotic data's variability.

Abiotic variables were correlated positively to $\mathrm{PCI}$ with structure coefficient higher than 0.5 . PCII was positively correlated to electric conductivity and negatively to $\mathrm{pH}$. PCIII was positively correlated to temperature and negatively to the pluviometric index (Tab. III).

Table III. Pearson's correlation between scores of principal components and log values of larvae and juveniles densities. (ns) Not significance at the stated significance level $(P<0,05)$.

\begin{tabular}{lccc}
\hline \multicolumn{1}{c}{ Variables/Components } & $\mathrm{PCl}$ & $\mathrm{PCI}$ & $\mathrm{PCIII}$ \\
\hline Water temperature & 0.613 & 0.043 & 0.587 \\
$\mathrm{pH}$ & 0.588 & -0.708 & -0.301 \\
Electric conductivity & 0.504 & 0.808 & 0.035 \\
Fluviometric level & 0.794 & $-0,220$ & 0.249 \\
Pluviometric index & 0.544 & 0.289 & -0.732 \\
Autovalues & 1.901 & 1.288 & 1.035 \\
Percentage of explanation & 38.010 & 25.760 & 20.700 \\
Correlation with log of larvae density & -0.197 & 0.387 & -0.691 \\
Probability & $\mathrm{ns}$ & 0.020 & 0.000 \\
Correlation with log of juveniles density & 0,212 & 0.056 & -0.188 \\
Probability & $\mathrm{ns}$ & $\mathrm{ns}$ & $\mathrm{ns}$ \\
\hline
\end{tabular}

Density variability of larvae and juveniles cannot be explained by the first linear combination (PCI) which maximizes abiotic data variance. With regard to the larvae, Pearson's correlation between principal components II and III and density values in the log scale was high. With regard to juveniles there was no significant correlation with any linear combination (Fig. 4). 

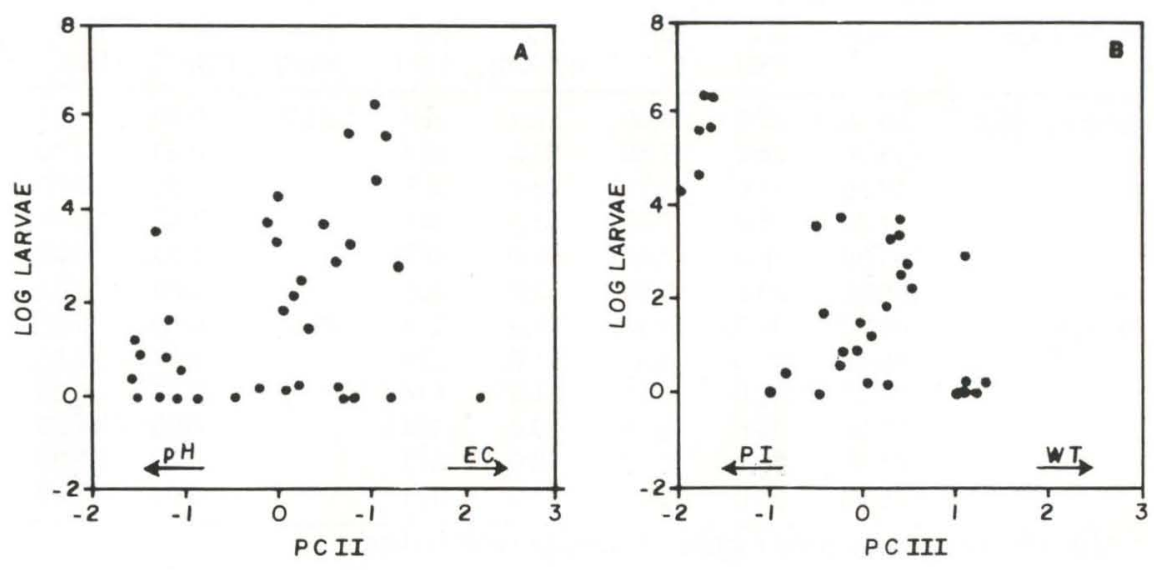

Fig. 4. Relationship between the log of larvae density and principal components II (A) and III (B).

\section{DISCUSSION}

The success in the colonization and the great expansion of M. amazonicum in the basin of Paraná River is probably due to its great capacity of adaptability and the reproductive strategy used. Reproduction through the whole year, relatively high fecundity and planktotrophic larvae cause this species to have appropriate characteristics to occupy environments which have severe drastic changes in the hydrologic regime (MAGALHÃES 1985).

Although reproduction of M. amazonicum in Central Amazon is continuous, there are three distinct peaks throughout the year: in mid low water period; in the dry period and in mid flooding period which is more intense (ODINETZ-COLLART 1991). This same reproductive behavior may be responsible for the great number of larvae and juveniles between August and December 1991, with a peak in the last month. This may be probably associated to the high pluviometric index observed in the region and to the rising of the river in this period. Organisms produced during this period take advantage of the rising in the water level. This factor favours survival since it diminishes intraspecies competition and predation due to an increase in food and available shelter.

Dispersion of shrimps caused by an increase of water volume was also studied by WALKER (1986) in the Amazon who registered the reproduction of $M$. inpa (Kensley \& Walker, 1982), M. nattereri (Heller, 1862), Pseudopalaemon chryseus (Kensley \& Walker, 1982) and Euryrhynchus amazoniensis (Tiefenbacher, 1978) during flooding and by LOBÃO et al. (1986b) who studied population of $M$. iheringii (Ortmann, 1897) of the Buava River in the state of São Paulo, Brazil. The latter recorded that the reproduction of this species occurred between December and January. 
As a general rule, larvae of $M$. amazonicum were captured in months with high values of the pluviometric index, $\mathrm{pH}$, electric conductivity and water temperature, as shown by the Principal Components Analysis. This is a period with the hottest months of the year and which also coincides to an increase in the fluviometric level. All these environmental variables seem to cause an intense reproductive process which is a common behaviour in tropical fish and shrimps during the flood period (ODINETZ-COLLART 1991).

TAKINO et al. (1989) studied the reproductive intensity of $M$. birai (Lobão, Melo \& Fernandes, 1986) in the Branco River, state of São Paulo, Brazil, and observed that the greatest reproduction occurred during the summer when the highest rainfalls and water temperature rising occurred. Similar data were obtained by CARVALHO et al. (1979) who studied the biology of M. acanthurus (Wiegmann, 1836) in the island of Itaparica, state of Bahia, Brazil. These authors showed that migration of these organisms was favoured by rains which is one of the most important factors in the richness of these organisms. VALENTI et al. (1986) also observed that spawning period of the various species of shrimp populations in the Ribeira de Iguape River, state of São Paulo, Brazil, coincided with the rainy and the hottest period of the year.

The great number of captures of the organisms during the night period seems to be explained by vertical migration. The phenomenon is very common in zooplanktonic organisms and is probably influenced by a higher food availability in the water column or by the flight of visual planktophagic predators. In the case of juveniles, besides the flight from predators, another factor is the avoidance of the capture apparatus during the period of light. MOREIRA \& ODINETZ-COLLART (1993) studied a floodplain lake of Central Amazon and also observed a greater concentration of larvae of this species at the surface during the first hours of the night at 22:00 hours, independently of the period of the year and of the type of habitat. However, the hypothesis of vertical migration cannot be confirmed in our studies since depth captures were not undertaken to observe the distribution of these organisms (they would probably be in the substratum) during the day.

Pearson's non-significant correlations between the principal components and the log of juvenile densities may have been caused by the indirect relationship with abiotic factors and by direct relationship to the number of larvae. An increase of the number of larvae also causes an increase in the number of juveniles which remain in the environment. This is probably due to the great availability of food and to favourable conditions to their development.

At present these organisms are an important food source for the various fish populations of the floodplain of the upper Paraná River. They are part of the diet of various carnivorous species such as Plagioscion squamosissimus (Heckel, 1864) and Raphiodon vulpinus (Agassiz, 1829) (ALMEIDA in press) and of omnivorous species such as Parauchenipterus galeatus (Linnaeus, 1766) and Pimelodus maculatus (La Cepede, 1803) (AGostiNHo et al. 1997) which participate in the alimentary chain. Besides, M. amazonicum is a commercial possibility still not explored in the region. The understanding of its life cycle will offer support for its possible rational exploration. 


\section{CONCLUSIONS}

Macrobrachium amazonicum is frequent in the upper Paraná River floodplain. Its presence is recent, and is a result of the introduction of species in the Paraná basin together with fishes. Due to its high capacity to adaptation and its reproductive strategy, this species showed fast development and now colonize the entire floodplain.

Time of reproduction is associated to environmental changes that occur between August and December, mainly by increase in pluviometric index, $\mathrm{pH}$, electric conductivity and water temperature. The high number of larvae and juveniles in these months suggest intense reproduction in this period, but during all year these phases are collected.

It is possible that this species develop vertical migration at night, probably searching for food, or scaping from visual planctophagous predators.

This species became an important food resource for some carnivorous and omnivorous fish species of the floodplain, and its is an unexploted comercial resource of the region.

ACKNOWLEDGEMENTS. The authors would like to thank The Research Nucleus in Limnology, Ichthyology and Aquiculture (Nupélia) for the help given during the collecting period and to Luiz Carlos Gomes (M.Sc) and Luis Mauricio Bini (M.Sc.) for the help given in statistical analyses.

\section{REFERENCES}

AgostinHO, A.A.; N.S. HAHN; L.C. Gomes \& L.M. BINI. 1997. Estrutura trófica. In: A.E.A DE M. VAzZoler; A.A. Agostinho, N.S. Hahn (Eds). A planície de inundação do alto rio Paraná: aspectos limnológicos e socioeconômicos. Maringá, EDUEM/NUPELIA, 453p.

ALMEIDA, V.L.L. (in press). Utilization of the alimentary resources by piscivorous fish of the high Paraná river floodplain $\left(22^{\circ} 40^{\prime}-22^{\circ} 50^{\prime} \mathrm{S}, 53^{\circ} 15-53^{\circ} 40^{\prime} \mathrm{W}\right)$, Brazil. Env. Bio. Fish.

BOND, G. \& L. BUCKUP. 1982. O ciclo reprodutor de Macrobrachium borellii (Nobili, 1896) e Macrobrachium potiuna (Müller, 1880) (Crustacea, Decapoda, Palaemonidae) e suas relações com a temperatura. Rev. Bras. Biol. 42 (3): 473-483.

1983. O cultivo de Macrobrachium borellii (Nobili, 1896) e Macrobrachium potiuna (Müller, 1880) em laboratório (Crustacea, Decapoda, Palaemonidae). Rev. Bras. Biol. 43 (2): 177-190.

BOND-BUCKUP, G. \& L. BUCKUP. 1989. Os Palaemonidae de águas continentais do Brasil Meridional (Crustacea, Decapoda). Rev. Brasil. Biol. 49 (4): 883-896.

CAMPos, J.B. \& M.C. SouZA. 1997. Vegetação, p.333-344. In: A.E.A DE M. VAZZoler; A.A. Agostinho, N.S. HAHn (Eds). A planície de inundação do alto rio Paraná: aspectos limnológicos e socioeconômicos. Maringá, EDUEM/NUPELIA, 453p. 
Carvalho, H.A.; M.G.S. Gomes; A.Q. Gondim \& M.C. Pereira. 1979. Sobre a biologia do pitú - Macrobrachium acanthurus (Wiegmann, 1836) em populações naturais da ilha de Itaparica. Universitas. 24: 25-45.

Coelho, P.A. \& M. Ramos-Porto. 1985. Camarões de água doce do Brasil: Distribuição Geográfica. Revta bras. Zool. 2 (6): 405-410.

Coelho, P.A.; M. Ramos-Porto; A.V. Barreto \& V.E. Costa. 1982. Crescimento em viveiro de cultivo do camarão canela (Macrobrachium amazonicum) (Decapoda, Palaemonidae). Revta bras. Zool. 1 (1): 45-49.

ELMOR, M.R.D.; V.L. LoBÃo \& W.C. VALENTI. 1981. Consumo de oxigênio por Macrobrachium acanthurus (Wiegmann, 1836) como subsísio do seu transporte e cultivo. Bol. Inst. Pesca, São Paulo, 8: 65-78.

Gomes-CorrêA, M.M. 1977. Palemonídeos do Brasil (Crustacea, Decapoda, Natantia). Dissertação de Mestrado, não publicada, Universidade Federal do Rio de Janeiro, Rio de Janeiro, 135p.

Holthuis, L.B. 1952. A general revision of the Palaemonidae (Crustacea, Decapoda, Natantia) of the Americas, II: The subfamily Palaemoninae, Occ. Pap. Allan. Hancock Found. 12: 1-396.

LoBÃo, V.L., P. SAWAYA. 1979. Crescimento e ciclo de muda em Macrobrachium holthuisi Genofre \& Lobão, 1976 (Crustacea, Decapoda). Bol. Inst. Pesca, São Paulo, 6: 1-16.

LoBÃO, V.L.; N.E.T. RoJAS \& W.C. VALENTI. 1986a. Fecundidade e fertilidade de Macrobrachium amazonicum (Heller, 1862) (Crustacea, Decapoda) em laboratório. Bol. Inst. Pesca., São Paulo, 13 (2): 15-20.

LoBÃo, V.L.; M.R.Z.N. Musto; N.E.T. RoJAS; M. LACE \& M.F.S. MAGALHÃES. 1986b. Estudo populacional de Macrobrachium inheringi (Ortmannt, 1897) (Decapoda, Palaemonidae) do rio Buava - SP. Bol. Inst. Pesca, São Paulo, 13 (2): 37-43.

MAGALHÃES, C. 1985. Desenvolvimento larval obtido em laboratório de palaemonídeos da região Amazônica. I. Macrobrachium amazonicum (Heller, 1862) (Crustacea, Decapoda). Amazoniana. 9 (2): 247-274.

MANLY, B.F.J. 1995. Multivariate statistical methods - A primer. London, Chapman \& Hall, XIII+215p.

MoReIRA, L.C. \& O. ODINETZ-CollarT. 1993. Migração vertical nictemeral das larvas de Macrobrachium amazonicum num lago de várzea na Amazônia Central, ilha do Careiro, Brasil. Amazoniana 12 (3/4): 1-8.

OdINETZ-CollaRT, O. 1988. Aspectos ecológicos do camarão Macrobrachium amazonicum (Heller, 1862) no baixo Tocantins (PA-Brasil). Mem. Soc. Cienc. Nat. La Salle. 48 (Supl.): 341-353.

1991. Strategie de reproduction de Macrobrachium amazonicum en Amazonie Centrale (Decapoda, Caridea, Palaemonidae). Crustaceana 61 (3): 253-270.

Odinetz-Collart, O. \& L.C. Moreira. 1993. Potencial pesqueiro de Macrobrachium amazonicum na Amazônia Central (Ilha do Careiro): variação da abundância e do comportamento. Amazoniana 12 (3/4): 399-414. 
TAKINO, M.; V.L. LOBÃO; T. GOLUBEFF \& J.V. LOMBARDI. 1989. Relações entre fatores climáticos e abióticos e o período reprodutivo das populações de Macrobrachium birai Lobão, Melo \& Fernandes e de Macrobrachium petronioi Melo, Lobão \& Fernandes (Decapoda, Palaemonidae) do rio Branco (Cananéia, SP, Brasil). Bol. Inst. Pesca, São Paulo, 16 (1): 67-80.

Torloni, C.E.C; J.J. Santos; A.A. Carvalho JR. \& A.R.A. CorrÊA. 1993. A pescada-do-piauí Plagioscion squamosissimus (Heckel, 1840) (Osteichthyes, Perciformes) nos reservatórios da Companhia Energética de São Paulo - CESP. São Paulo, CESP, Série Pesquisa e Desenvolvimento, 23p.

VALENTI, W.C.; J.T.C. MELlo \& V.L. LoBÃo. 1986. Dinâmica da reprodução de Macrobrachium acanthurus (Wiegmann, 1836) e Macrobrachium carcinus (Linnaeus, 1758) do rio Ribeira de Iguape (Crustacea, Decapoda, Palaemonidae). Ciênc. Cult. 38 (7): 1256-1262).

WALKER, I. 1986. Sobre a ecologia e biologia da decomposição da matéria orgânica em águas amazônicas. Acta Limnol. Brasil. 1: 557-573.

Recebido em 26.IX.1996; aceito em 10.VI.1997. 